\title{
Reduced Prolactin and Cortisol Responses to d-Fenfluramine in Depressed Compared to Healthy Matched Control Subjects
}

\author{
Anthony J. Cleare, M.B., B.S., M.R.C. Psych., Robin M. Murray, M.D., F.R.C. Psych.,
} and Veronica O'Keane, Ph.D., M.R.C. Psych.

\begin{abstract}
d-Fenfluramine, a specific 5-HT releasing agent without the catecholamine effects of $d, l$-fenfluramine, was used as a neuroendocrine challenge in 19 subjects with major depression and 19 healthy controls. Patients and controls were matched for age, sex, weight, and menstrual status. 5-HT-mediated prolactin and cortisol responses were both significantly attenuated in the depressed group. Patients with a history of a suicide attempt had lower cortisol
\end{abstract}

responses than those without. Peak cortisol responses were inversely related to baseline cortisol levels. There were also significant relationships between hormone responses and both age and weight. These findings replicate those of a previous study using this challenge and reiterate the role of reduced 5-HT activity in suicide. They also reinforce the need for careful matching in neuroendocrine studies.

[Neuropsychopharmacology 14:349-354, 1996]
KEY WORDS: Major depression; d-Fenfluramine; Serotonin; Cortisol; Prolactin; Suicide

The 5-hydroxytryptamine (5-HT) hypothesis of depression implicates reduced central 5-HT neurotransmission as the underlying biochemical deficit in depression (Maes and Meltzer 1995) and is supported by studies using diverse methodologies (Ecclestone and Doogan 1991). In particular, psychoneuroendocrine studies using a variety of 5-HT probes have been performed to obtain an accurate index of the overall functional status of central 5-HT systems (Checkley 1980). Many studies have used racemic d,l-fenfluramine, a 5-HT releasing agent, as a challenge drug. 5-HT release from the raphe nuclei projections to the hypothalamus results in secretion of prolactin (PRL) and adrenocorticotrophic hormone (ACTH)

From the Department of Psychological Medicine, Institute of Psychiatry, London, England.

Address correspondence to: Anthony J. Cleare, Department of Psychological Medicine, Institute of Psychiatry, De Crespigny Park, London SE5 8AF, England.

Received March 10, 1995; revised June 30, 1995; accepted July 19, 1995 from the pituitary and subsequently of cortisol (CORT) from the adrenal cortex. Measuring PRL and CORT responses gives an index of central 5-HT responsivity (Quattrone et al. 1983). The results of studies using $\mathrm{d}, \mathrm{l}$-fenfluramine challenge have been inconsistent, though. Siever et al. (1984), Lopez-Ibor et al. (1988), and Lichtenberg et al. (1992) showed a blunted PRL response in depressed patients, whereas Mitchell and Smythe (1990) showed reduced responses only in those who were endogenously depressed. Weizman et al. (1988) failed to find any differences in PRL response between controls and depressives. However, none of these studies matched subjects simultaneously for age, sex, weight, and menstrual cycle, and frequently they included both bipolar and unipolar patients. Furthermore, d,l-fenfluramine has been criticized as insufficiently specific as a serotonergic probe, because it has additional effects on other monoamine systems (Van Praag et al. 1986).

The d-isomer of fenfluramine is a more 5-HT-specific probe, being free of the catecholamine effects of racemic d,l-fenfluramine (Invernizzi et al. 1986; Garattini et al. 1987). Circulating PRL and CORT concentrations have been reliably demonstrated to rise following adminis- 
tration of $30 \mathrm{mg}$ of d-fenfluramine (O'Keane et al. 1991; Feeney et al. 1993; Goodall et al. 1993; Gorard et al. 1993). The absence of any dopaminergic effects with d-fenfluramine allows more certainty in the interpretation of the prolactin response as a 5-HT-mediated effect, because PRL is also under dopaminergic control (Gudelsky et al. 1984).

O'Keane and Dinan (1991) compared endocrine responses to $30 \mathrm{mg}$ of $\mathrm{d}$-fenfluramine in unmedicated depressed patients and controls and found reduced PRL and CORT responses in 23 patients with depression compared to 16 control subjects. However, patients and controls were not matched for sex or weight, both of which may independently affect hormonal responses (Altomonte et al. 1987; McBride et al. 1990). These results contrast with those of Maes et al. (1991), who failed to find any difference between major depressives and controls using $45 \mathrm{mg}$ of d-fenfluramine.

The present study tested the 5-HT hypothesis of depression using a similar neuroendocrine procedure to that of O'Keane and Dinan (1991), but carefully matched test and control subjects.

\section{METHOD}

\section{Subjects}

Nineteen depressed patients ( 7 male, 12 female) were recruited from referrals to the Maudsley Hospital. Fifteen of the 19 were psychotropic drug naive, and all, except two females taking hormone replacement therapy, were drug free at the time of testing for at least 3 months. All patients were suffering from major depressive disorder (MDD) according to the criteria of the Diagnostic and Statistical Manual of Mental Disorders, (DSM-III-R; APA 1987) and scored at least 17 on the 17item Hamilton Rating Scale for Depression (HAM-D; Hamilton 1960). Patients with additional DSM-III-R diagnoses or bipolar depression were excluded. None of the patients was psychotic, but six were suffering from DSM-III-R melancholic subtype. Four had a history of a suicide attempt: two had taken an overdose in the past, one had taken three previous overdoses, one during the present episode, and one had taken an overdose and cut her wrists during the presenting illness. A control group of 19 subjects was recruited from staff and student volunteers at the hospital, matched for sex, age, and weight. Females were tested at the same stage of their menstrual cycle or hormone replacement regime; 4 pairs were early follicular (day $1-7), 6$ were luteal (day 20-28), and 2 were on equivalent doses of estrogen only hormone replacement therapy. Mean ages $( \pm S D)$ were $39.3 \pm 15.2$ years in the depressed and $36.5 \pm 7.2$ years in the control group. Weights averaged $65.7 \pm 12.3 \mathrm{~kg}$ and $69.8 \pm 13.6 \mathrm{~kg}$ in the depressed and control groups, respectively. All subjects gave written informed consent.

\section{Procedures}

Subjects were cannulated at 9:00 A.M. having fasted from midnight. Following a 15-minute relaxation period, first blood samples were taken and $30 \mathrm{mg}$ of d-fenfluramine was administered orally. Subjects remained semirecumbent for the next 5 hours and further samples were taken at 1, 3, 4, and 5 hours. A standard light snack was served after one hour.

Analysis of serum PRL and CORT concentrations was carried out blind to patient status in the Department of Clinical Biochemistry, King's College Hospital. The prolactin was assayed using the immunoradiometric method MAIAClone from Serono (Hampshire, UK) described by Rattle et al. (1984), and CORT was assayed using the Coat-A-Coat radioimmunoassay from DPC (California, USA). The inter-assay coefficient of variance was less than $6 \%$ for both assays.

\section{Analysis}

Peak hormone responses ( $\Delta$ values) were calculated by subtracting baseline values from the maximum levels post d-fenfluramine administration. Hormone levels fell sharply between 0 and 60 minutes, representing recovery from the stress response of cannulation and natural circadian falls. Sixty-minute values therefore constituted a more accurate baseline. Peak and baseline hormonal measures were compared between patients and controls using one-way analysis of variance (ANOVA). In addition, a one-way ANOVA (at each time point) and a repeated-measures two-way ANOVA were performed on the PRL and CORT change from baseline over time. To confirm differences in post-drug hormone responses, area under the curve (AUC) calculations were made using the trapezoid method on hormonal responses and similarly compared between patients and controls. Correlations were performed using Pearson's productmoment analysis. Means are expressed \pm SD.

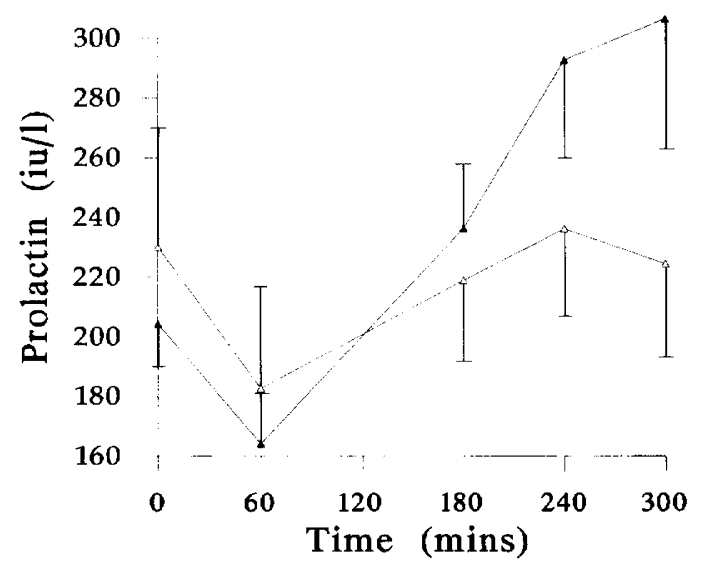

Figure 1. Mean serum prolactin concentrations in depressed and control groups after oral administration of $30 \mathrm{mg}$ of d-fenfluramine. $(\triangle$ controls $(n=19) ;-\checkmark$ depressed $(n=19))$. 


\section{RESULTS}

There were no differences in mean age $\left(F_{1,36}=1.18 ; p>\right.$ $.1)$ or weight $\left(F_{1,36}=1.24 ; p>.1\right)$ between patients and controls. Patients' HAM-D scores averaged $22.8 \pm 3.5$.

Baseline PRL was $183 \pm 95 \mathrm{iu} / \mathrm{L}$ in the depressed group and $164 \pm 69 \mathrm{iu} / \mathrm{L}$ in the controls $\left(F_{1,36}=0.5 ; p>\right.$ .1). The mean $\triangle \mathrm{PRL}$ response in the depressed group (75 $\pm 108 \mathrm{iu} / \mathrm{L})$ was significantly lower than that of the control group $(186 \pm 153 \mathrm{iu} / \mathrm{L})\left(F_{1,36}=6.7 ; p=.01\right)$. Figure 1 shows the comparative PRL responses. The ANOVA on the PRL response showed a significantly lower change from baseline in the depressed group at 4 hours $\left(F_{1,36}=\right.$ $6.9 ; p=.01)$ and 5 hours $\left(F_{1,36}=7.8 ; p=.008\right)$. A significant overall group-by-time interaction was also present $\left(F_{4,180}=3.79 ; p=.006\right)$, confirming the blunted curve in the depressed group. The 2 groups showed similar differences when AUCs were compared. Mean AUC PRL was $98 \pm 279 \mathrm{iu} . \mathrm{h} / \mathrm{L}$ in the depressed and $308 \pm 215 \mathrm{iu} . \mathrm{h} / \mathrm{L}$ in the controls $\left(F_{1,36}=6.7 ; p=.01\right)$. There were no groupby-sex differences for PRL responses or AUC PRL results.

Baseline CORT was elevated in the depressed group $(451 \pm 197 \mathrm{nmol} / \mathrm{L})$ compared to the controls $(267 \pm 96$ $\mathrm{nmol} / \mathrm{L})\left(F_{1,36}=11.4 ; p=.002\right)$. The mean $\Delta$ CORT value was significantly attenuated in the patient $(61 \pm 25$ $\mathrm{nmol} / \mathrm{L})$ relative to control group $(186 \pm 31 \mathrm{nmol} / \mathrm{L})$ $\left(F_{1,36}=9.9 ; p=.003\right)$. Figure 2 shows the CORT responses over time. The ANOVA on the CORT response showed a significantly lower change from baseline in the depressed group at 3 hours $\left(F_{1,36}=7.7 ; p=.009\right), 4$ hours $\left(F_{1,36}=8.2 ; p=.007\right)$, and 5 hours $\left(F_{1,36}=9.4 ; p=\right.$ $.004)$. The overall group-by-time interaction was also significant $\left(F_{4,180}=2.60 ; p=.04\right)$, showing a blunted curve in the depressed group. The AUC CORT value was $-62.4 \pm 350 \mathrm{nmol} . \mathrm{h} / \mathrm{L}$ in the depressed group and $299 \pm 310 \mathrm{nmol} . \mathrm{h} / \mathrm{L}$ in the controls, a significantly lower

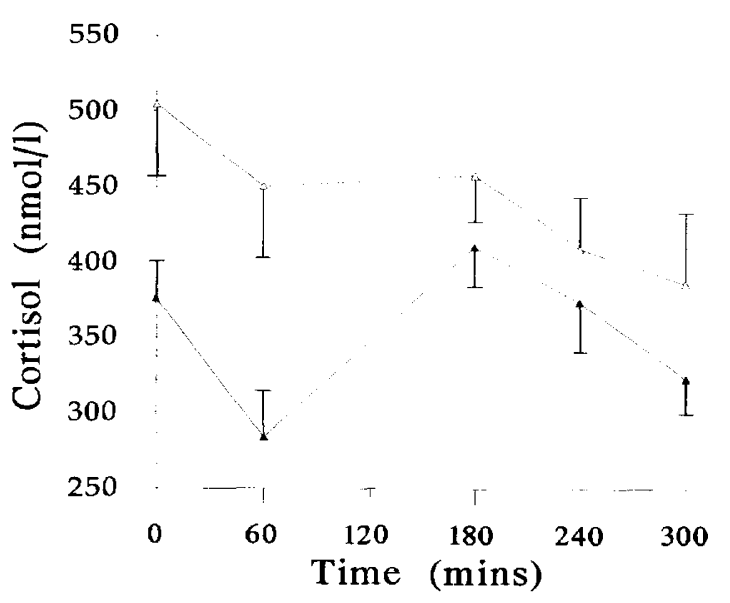

Figure 2. Mean serum cortisol concentrations in depressed and control groups after oral administration of $30 \mathrm{mg}$ of d-fenfluramine. $(\triangle$ controls $(n=19) ;-\triangle$ depressed $(n=19))$. value $\left(F_{1,36}=11.4 ; p=.002\right)$. There were no group-bysex differences for CORT or AUC CORT responses.

Melancholic patients did not differ from nonmelancholics on any hormonal variables. The presence of weight loss or psychomotor retardation did not significantly affect the responses in depressed patients, but the presence of a history of suicide attempt did. In those with a positive history the mean $\Delta$ CORT was significantly attenuated $(-53 \pm 74 \mathrm{nmol} / \mathrm{L}$ compared to $91 \pm 96$ $\left.\mathrm{nmol} / \mathrm{L} ; F_{1,17}=7.3 ; p=.01\right)$. The $\Delta \mathrm{PRL}$ responses were $62 \pm 150 \mathrm{iu} / \mathrm{L}$ in attempters and $78 \pm 99 \mathrm{iu} / \mathrm{L}$ in nonattempters $\left(F_{1,17}=.06 ; p>.1\right)$.

Correlational analysis for the whole group revealed a significant negative correlation between baseline CORT and $\triangle$ CORT responses $(r=0.63 ; p<.001)$ and AUC CORT $(r=0.75 ; p<.001$; see Figure 3$)$, but no relationship between baseline CORT and $\triangle P R L$ or AUC PRL. However, analyzing men alone did produce a weak relationship in the same direction between baseline CORT and AUC PRL $(r=0.51 ; p=.06)$. The $\Delta$ CORT responses were positively correlated to $\triangle \mathrm{PRL}$ responses $(r=0.40$; $p=.01$ ). There was a positive relationship between weight and $\triangle$ CORT $(r=0.40 ; p=.01)$ and an inverse relationship between age and $\triangle$ PRL $(r=0.34 ; p=.04)$. There were no correlations between hormonal variables and HAM-D total score and HAM-D suicide or retardation parameters.

\section{DISCUSSION}

Both the PRL and CORT responses to d-fenfluramine were attenuated in the depressed group. These findings suggest that 5-HT neurotransmission, as measured by this method, is reduced in MDD. This study extends the original findings of O'Keane and Dinan (1991) by using

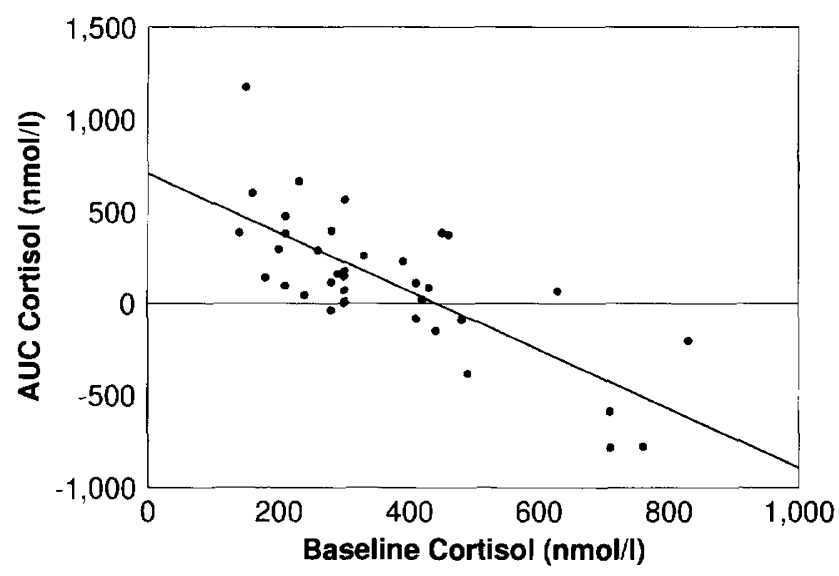

Figure 3. Baseline cortisol concentrations plotted against the $\mathrm{d}$-fenfluramine-induced cortisol response, measured as area under the curve (AUC, relative to baseline). $(r=-0.75$, $\mathrm{p}<0.001$.) 
a more closely matched control group. That this matching is important in neuroendocrine studies is confirmed by the presence of significant relationships between weight and $\triangle C O R T$ and age and $\triangle P R L$. Other studies have also found that such factors can confound interpretation of neuroendocrine responses (McBride et al. 1987; Altomonte et al. 1990; O'Keane et al. 1991). Also, by using d-fenfluramine as a 5-HT probe we have overcome many of the theoretical shortcomings of d,l-fenfluramine. Interestingly, though, one preliminary study suggested that the effects of these two drugs, at least on prolactin release, may be similar in many subjects (Coccaro et al. 1994).

Possible shortcomings with our findings include the lack of d-fenfluramine plasma levels to exclude totally pharmacokinetic explanations for the inter-group differences. However, patients and controls were weight matched, lessening the likelihood that there were large enough differences in plasma levels to explain the large observed hormonal differences. We did not measure $\mathrm{ACTH}$ levels directly either, and so cannot exclude the possibility that $\mathrm{d}$-fenfluramine may have had direct effects on adrenal cortical cortisol secretion (Van de Kar et al. 1985; Hollander et al. 1993). The dose of d-fenfluramine we used was $30 \mathrm{mg}$, for which there is good placebo-controlled data. Although some previous studies used a 45-mg challenge dose, human data on this dose are less complete. Furthermore, $45-\mathrm{mg}$ doses have a higher incidence of unpleasant side effects during testing (T. Dinan 1995, personal communication), which increase the risk of nonspecific stress responses. All but four of our sample were psychotropic drug naive, minimizing the possibility of drug-induced changes accounting for reduced 5-HT responsivity. Finally, none had histories of bipolar depression, suggesting perhaps more homogeneity than in previous studies, which included both unipolar and bipolar patients.

d-Fenfluramine is a releasing agent and does not act specifically at 5 -HT receptor subtypes. Thus blunted responses are indicative of an overall reduction in hypothalamic 5-HT activity. This may result from: (1) reduced availability of 5-HT for release because of reduced presynaptic stores, impaired sensitivity of presynaptic neurones in the raphe nuclei, or other mechanisms; or (2) reduced postsynaptic receptor sensitivity. In humans PRL responses to d-fenfluramine may be mediated by 5- $\mathrm{HT}_{2 \mathrm{~A} / 2 \mathrm{C}}$ receptors (Goodall et al. 1993), $5-\mathrm{HT}_{1 \mathrm{~A}}$ receptors (Palazidou et al. 1995), or an interaction of both. 5-HT-dependent ACTH and CORT release may also be dependent on $5-\mathrm{HT}_{1 \mathrm{~A}}$ receptors (Lesch et al. 1990a, $1990 \mathrm{~b}$ ) and $5-\mathrm{HT}_{2 \mathrm{~A} / 2 \mathrm{C}}$ receptors (Gartside and Cowen 1990). Thus both receptor subtypes may be important in the hormonal responses we measured. Research has generally indicated that $5-\mathrm{HT}_{2 \mathrm{~A} / 2 \mathrm{C}}$ receptors are upregulated in depression, whereas $5-\mathrm{HT}_{1 \mathrm{~A}}$ receptors are downregulated (Maes and Meltzer 1995). It is not easy therefore to link the blunted responses to any specific postsynaptic receptor abnormalities. Similar difficulties occur when interpreting the results of challenges with agents such as l-tryptophan, 5-hydroxytryptophan, and clomipramine. Studies using these agents have been taken to provide support for the hypothesized $5-\mathrm{HT}_{2 \mathrm{~A} / 2 \mathrm{C}}$ receptor upregulation and $5-\mathrm{HT}_{1 \mathrm{~A}}$ receptor downregulation. However, these challenge drugs are not specific to any 5-HT receptors and, unlike d-fenfluramine, may also have effects on catecholamine systems (Van Praag et al. 1986). Our interpretation, therefore, is that the blunted hormonal response to d-fenfluramine reflects a functional reduction of central serotonergic neurotransmission, but we are not able to identify precisely which receptors are affected.

In order to determine accurately the effects on individual postsynaptic receptor subtypes in MDD, testing with more highly specific receptor agonists is required. $5-\mathrm{HT}_{1 \mathrm{~A}}$ agonists have already been used in this respect, confirming subsensitivity of the ACTH and cortisol response to these receptors when the highly specific agent ipsapirone is used (Lesch et al. 1990a, 1990b), but not when the much less specific buspirone is used (Cowen et al. 1994; Meltzer and Maes 1994). Unfortunately, there are no specific $5-\mathrm{HT}_{2 \mathrm{~A}}$ or $5-\mathrm{HT}_{2} \mathrm{C}$ postsynaptic receptor agonists available for use in humans at the present time.

Baseline cortisol was significantly raised in depressed patients, a consistently replicated finding (Dinan 1994). Previous neuroendocrine studies have found that 5-HTmediated endocrine responses are inversely related to cortisol levels (Deakin et al. 1990; Dinan 1994). One study investigating MDD prior to and following treatment found that reduction in circulating cortisol concentrations to normal levels was the strongest predictor of normalization of the d-fenfluramine/PRL response (O'Keane et al. 1992). Preclinical studies have demonstrated that glucocorticoids exert a powerful regulatory effect on central 5-HT neurotransmitter function. For example, increased glucocorticoid activity caused downregulation of 5-HT $1 \mathrm{~A}$ receptors (De Kloet et al. 1986) and reduced $5-\mathrm{HT}_{1 \mathrm{~A}}$ receptor $\mathrm{m}-\mathrm{RNA}$ expression (Chalmers et al. 1994). Thus the reduced functional 5-HT activity in depression is increased back to normal by lowering serum cortisol with cortisol synthesis inhibitors (Thakore and Dinan 1995).

These findings have led to the hypothesis that hypercortisolemia, secondary to ongoing psychosocial stressors (Deakin et al. 1990) or abnormal stress responses (Dinan 1994), gives rise to the reduced brain monoamine function in depression. Our finding of a strong inverse relationship between $\triangle C O R T$ responses and hypercortisolemia is consistent with this hypothesis, although ACTH measures would provide stronger direct evidence. The relationship with $\triangle P R L$ responses in this sample was weaker and confined to men. The absence of such a relationship in women may be due to the differing stages of the men- 
strual cycle at which they were tested. Although this variable was controlled for when comparing groups, on a within-group correlation, the marked differences in $\mathrm{d}$-fenfluramine/PRL responses through the menstrual cycle ( $\mathrm{O}^{\prime}$ Keane et al. 1991) introduce a significant third factor that adds variance and could obscure the relationship. Previous studies that found this correlation tested women who were all in the follicular stage of the cycle (O'Keane and Dinan 1991).

Another interesting finding was the lower 5-HT responsivity in patients with a history of suicide attempts. This is consistent with numerous studies finding suicide to be associated with measures of reduced 5-HT function (Roy and Linnoila 1988). This finding parallels that of Coccaro et al. (1989), who found PRL responses to d,l-fenfluramine similarly reduced in depressed and personality disordered patients with histories of suicide attempts. Indeed, Neilsen et al. (1994) suggested that low 5-HT activity is a trait marker for impulsive behavior in general, including suicide. It is interesting to speculate on whether these individuals have a reduced responsivity to $\mathrm{d}$-fenfluramine as a marker in between depressive episodes or a tendency to a more severe reduction while depressed. Longitudinal studies might provide the answer.

In conclusion, this study provides further evidence in support of the 5-HT hypothesis of depression and for the role of $5-\mathrm{HT}$ in suicide.

\section{ACKNOWLEDGMENTS}

We are grateful to Organon Laboratories, which provided financial support for this study, and to Joan Butler and Roy Sherwood for their help in performing hormone assays.

\section{REFERENCES}

Altomonte L, Zoli A, Alesi F, Ghirlandi G, Manna R, Greco A 1987): Effects of fenfluramine on GH and PRL secretion in obese subjects. Horm Res 27:190-194

American Psychiatric Association (1987): Diagnostic and Statistical Manual of Mental Disorders, ed 3, rev, Washington DC, American Psychiatric Association

Asnis GM, Eisenberg J, van Praag HM, Lemus CZ, Friedman JM, Miller AH (1988): The Neuroendocrine response to fenfluramine in depressives and normal controls. Biol Psychiatr 24:117-120

Chalmers DJ, Lopez JF, Vazquez DM, Akil H, Watson SJ (1994): Regulation of hippocampal $5-\mathrm{HT}_{1 \mathrm{~A}}$ receptor gene expression by dexamethasone. Neuropsychopharmacology 10:215-222

Checkley SA (1980): Neuroendocrine tests of monoamine function in man: A review of basic theory and its application to the study of depressive illness. Psycholog Med 10:35-53

Coccaro E, Siever LJ, Klar HM, Maurer G, Cochrane K,
Cooper TB, Mohs RC, Davis KL (1989): Serotonergic studies in patients with affective and personality disorders. Correlates with suicidal and impulsive aggressive behavior. Arch Gen Psychiatr 46:587-599

Coccaro EF, Kavoussi RJ, Hauger R (1994): PRL and HVA responses to D- and D,L-fenfluramine in humans. Biol Psychiatr 35:644

Cowen PJ, Power AL, Ware CJ, Anderson IM (1994): $5-\mathrm{HT}_{1 \mathrm{~A}}$ receptor sensitivity in major depression. A neuroendocrine study with buspirone. Br J Psychiatr 164:372-379

Deakin JFW, Pennell I, Upadhyaya AJ, Lofthouse R (1990): A neuroendocrine study of 5-HT function in depression: Evidence for biological mechanisms of endogenous and psychosocial causation. Psychopharmacology 101:85-92

De Kloet E, Sybesma H, Reul JMHM (1986): Selective control by corticosterone of serotonin-1 receptors capacity in raphe-hippocampal system. Neuroendocrinology 42 : 513-521

Dinan TG (1994): Glucocorticoids and the genesis of depressive illness. Br J Psychiatr 164:365-372

Ecclestone D, Doogan D (1989): Serotonin and behavioural disorders. Br J Psychiatr 8(suppl):7-69

Feeney S, Goodall E, Silverstone T (1993): The prolactin response to $\mathrm{d}$ - and l-fenfluramine and to d-amphetamine in human subjects. Int Clin Psychopharmacol 8:49-54

Garattini S, Mennini T, Samanin, R (1987): From fenfluramine racemate to d-fenfluramine. Ann N Y Acad Sci 499:156-166

Gartside SE, Cowen PJ (1990): Mediation of ACTH and prolactin responses to $5-\mathrm{HTP}$ by $5-\mathrm{HT}_{2}$ receptors. Eur J Pharmacol 179:103-109

Goodall EM, Cowen J, Franklin M, Silverstone T (1993): Ritanserin attenuates anorectic, endocrine and thermic responses to d-fenfluramine in human volunteers. Psychopharmacology 112:461-466

Gorard TM, Taylor TM, Medbak LA, Perry LA, Libby GW, Farthing MJG (1993): Plasma prolactin, adrenocorticotrophic hormone and cortisol after administration of d-fenfluramine or placebo to healthy subjects. Int Clin Psychopharmacol 8:123-128

Gudelsky GA, Simonovic M, Meltzer HY (1984): Dopaminergic and serotonergic control of neuroendocrine function. Monographs in Neural Sciences 10:85-102

Hamilton M (1960): A rating scale for depression. J Neurol Neurosurg Psychiatr 23:56-62

Hollander E, Cohen LJ, DeCaria C, Saoud JB, Stein DJ, Cooper TB, Islam NN, Liebowitz MR, Klein DF (1993): Timing of neuroendocrine responses and effect of $\mathrm{m}-\mathrm{CPP}$ and fenfluramine plasma levels in OCD. Biol Psychiatr 34: $407-413$

Invernizzi R, Berettera C, Garratini S, Samanin R (1986): D- and L-isomers of fenfluramine differ markedly in their interaction with brain serotonin and catecholamines in the rat. Eur J Pharmacolo 120:9-15

Lesch K-P, Sohnle K, Poten B, Schoellnhammer G, Rupprecht R, Schulte HM (1990a): Corticotrophin and cortisol secretion after central $5-\mathrm{HT}_{1 \mathrm{~A}}$ receptor activation: Effect of 5-HT receptor and beta-adrenoceptor antagonists. J Clin Endocrinol Metab 70:670-674

Lesch K-P, Mayer S, Disselkamp-Tietze J, Hoh A, et al (1990b): $5-\mathrm{HT}_{1 \mathrm{~A}}$ receptor responsivity in unipolar depression: Eval- 
uation of ipsapirone-induced ACTH and cortisol secretion in patients and controls. Biol Psychiatr 28:620-628

Lichtenberg P, Shapira B, Gillon D; Kindler S, Cooper TB, Newman ME, Lerer B (1992): Hormone responses to fenfluramine and placebo challenge in endogenous depression. Psychiatry Res 43:137-146

Lopez-lbor JJ Jr, Saiz Ruiz J, Iglesias M (1988): The fenfluramine challenge test in the affective spectrum: A possible marker of endogenicity and severity. Pharmacopsychiatry 21:9-14

Maes M, Meltzer HY (1995): The serotonin hypothesis of major depression. In Bloom FE, Kupfer DJ (eds), Psychopharmacology, the Fourth Generation of Progress, New York, Raven, pp 933-944

Maes M, D'Hondt P, Suy E, Minner B, Vandervorst C, Raus J (1991): HPA-axis hormones and prolactin responses to dextro-fenfluramine in depressed patients and healthy controls. Prog Neuropsychopharmacol Biol Psychiatr 15:781-790

McBride A, Ierney H, DeMeo M, Chen J-S, Mann JJ (1990): Effects of age and gender on serotonergic responsivity in normal adults. Biol Psychiatr 27:1143-1155

Meltzer HY, Maes M (1994): Effects of buspirone on plasma prolactin and cortisol levels in major depression and normal subjects. Biol Psychiatry 35:316-323

Mitchell P, Smythe G (1990): Hormonal responses to fenfluramine in depressed and control subjects. J Affect Dis 19:43-51

Neilsen DA, Goldman D, Virkunnen M, Tokola R, Rawlings R, Linnoila M (1994): Suicidality and 5-hydroxyindoleacetic acid concentration associated with a tryptophan hydroxylase polymorphism. Arch Gen Psychiatr 51:34-38

O'Keane V, Dinan TG (1991): Prolactin and cortisol responses to d-fenfluramine in major depression: Evidence for diminished responsivity of central serotonergic function. Am J Psychiatr 148:1009-1015

O'Keane V, O'Hanlon M, Webb M, Dinan TG (1991): d-Fenfluramine/prolactin response throughout the menstrual cycle: Evidence for an oestrogen-induced alteration. Clin Endocrinol 34:289-292

O'Keane V, McLoughlin D, Dinan T (1992): d-Fenfluramine induced prolactin and cortisol release in major depression: Response to treatment. J Affect Dis 26:143-150

Palazidou E, Stephenson T, Butler J, Coskeran P, Chambers S, McGregor A (1995): Evidence for $5-\mathrm{HT}_{1 \mathrm{~A}}$ receptor involvement in the control of prolactin secretion in man. Psychopharmacology 119:311-314

Quattrone A, Tedeschi G, Aguglia U, Scopacasa F, Di Renzo GF, Annunziato L (1983): Prolactin secretion in man: A useful tool to evaluate the activity of drugs acting on central 5-hydroxytryptaminergic neurones. Studies with fenfluramine. Br J Clin Pharmacol 16:471-475

Rattle SJ, Purnell DR, Williams PIM, Siddle K, Forrest GC (1984): New separation method for monoclonal immunoradiometric assays for thyrotropin and human choriogonadotropin. Clin Chem 30:1457-1461

Roy A, Linnoila M (1988): Suicidal behavior, impulsiveness and serotonin. Acta Psychiatr Scand 78:529-535

Siever LJ, Murphy DL, Slater S, De La Vega E, Lipper S (1984): Plasma prolactin changes following fenfluramine in depressed patients compared to controls: An evaluation of central serotonergic responsivity in depression. Life Sci 34:1029-1039

Thakore J, Dinan TG (1995): Cortisol synthesis inhibition: A new treatment strategy for clinical and endocrine manifestations of depression. Biol Psychiatr 37:364-368

Van de Kar LD, Karteszi M, Bethea CL, Ganong WF (1985): Serotonergic stimulation of prolactin and corticosterone secretion is mediated by different pathways from the mediobasal hypothalamus. Neuroendocrinology 41:380-384

Van Praag HM, Lemus C, Kahn R (1986): Hormonal probes of central serotonergic activity: Do they really exist? Biol Psychiatr 22:86-98

Weizman A, Mark M, Gil-Ad I, Tyano S, Laron Z (1988): Plasma cortisol, prolactin, growth hormone, and immunoreactive beta-endorphin response to fenfluramine challenge in depressed patients. Clin Neuropharmacol 11: $250-256$ 